\title{
Re-thinking COVID-19's causation narrative
}

by

Junior (Jay) Campbell

Abstract: The COVID-19 narrative has been the story of a pathogen, probably created in a Chinese wet market, somehow jumping from the animal kingdom into the human population and basically destroying our bodies from within by virtue of its reproductive rapacity or viral "virility".

Efforts have therefore tended to focus on understanding the SARS-CoV-2 virus that causes COVID-19, to find an effective cure for this disease.

However, given COVID-19's well documented impact on the mind, inducing delirium, feelings of exhaustion and other psychosomatic manifestations, called "malaise" by a British Medical Journal (BMJ) article cited here 
extensively, might it be worth considering the possibility that SARS-CoV-2's virility and reproductive efficacy is interdependent with a radical (albeit gradual, possibly), change in human bio-psychology?

In other words, might some seismic alteration in human bio-psychology and psychosocial relations have occurred that predisposes human beings to infection with the SARS-CoV-2 virus, of which the delusions and other neurological or bio-psychological disease insults are "atypical" symptoms?

Might the much noted penetrative, or binding power of the protein spikes on the envelope which surrounds the virus' core genetic material be a consequence of or a complement to a catastrophic, or at least perilous biopsychological permeability that has opened up in the individual consciences and/or collective unconscious of human beings, much like the hole in the earth's ozone layer?

Might the much noted higher covid-19 death rates among males point to or reflect a distinct, possibly "new" phase in humanity's perennial, existential battle of the 
sexes: a phase predicted approximately 3000 years ago by Jeremiah, a Jewish prophet?

"How long will you wander, O faithless daughter?

For the LORD has created a new thing in the land - a woman will surround a man," reads Jeremiah 31:22.

These words may be viewed as a kind of "abstract" and preamble to the more elaborate description and explanation of that "new thing", the unwritten New Covenant (NC), in verses 31 to 34 :

Behold, the days are coming, declares the LORD, when I will make a new covenant with the house of Israel and with the house of Judah.

It will not be like the covenant I made with their fathers when I took them by the hand to lead them out of Egypt - a covenant they broke, though I was a husband to them," declares the LORD.

"But this is the covenant I will make with the house of Israel after those days, declares the LORD. I will put My law in their minds and inscribe it on their 
hearts. And I will be their God, and they will be My people.

No longer will each man teach his neighbor [or] his brother, saying, 'Know the LORD,' because they will all know Me, from the least of them to the greatest, declares the LORD. For I will forgive their iniquity and will remember their sins no more."

Consistent with the distinction I make between that unwritten, conscience (heart and mind) oriented New Covenant (NC) dynamic prophesied by Jeremiah in that same chapter (verses 31 to 34 ) and the written New Testament (NT) that has surreptitiously displaced it, I am not proposing a one-to-one mapping of biblical (or biographical) and biological referents and meaning: I am merely pointing to, or in epidemiological terms, "tracking and tracing", the outline of a truth, or better, an incarnation or "body of truth" that mirrors male-female procreational interdepence. 
As I argue in a related Publishizer project, COVID-19 can very usefully be construed as a Couvade, phantom pregnancy mirroring procreational dynamic.

And I am proposing that this male-female interdependence mirroring, covid-19 causation narrative - this possibile explanation of that contagion's origin and/or mode of operation - is worth considering on the basis of known bio-psychological precedents.

And chief among these precedents, from my perspective, is the viral spread of the legalistic, written-NTforegrounding, unwritten, conscience (heart and mind) oriented NC suppressing version of Christendom in the first to fourth century Roman empire.

I am proposing that like the spread of Nazism in the 1930s, its contemporary, resuscitated forms of Afrocentric and Eurocentric nationalism (the former cloaked in the academic garb of Sir Hilary Beckles', Dr Margaret Gill's and others' "critical race theory", the latter associated with United States president Donald Trump's racial reactionary presidency), fundamentalist feminist phenomena, violent strains of Jihadi Islam, a subtle, Jihadi mirroring, fascist "gay gospel" presumption 
and militancy and other divisive, social cohesion eroding strains of toxic thinking and testaments are implicated in a psycho-social contagion that has made humanity so "batty" that we are more susceptible than we might otherwise be to a virus that may have originated in the bodies of bats.

And I note the similarity of the Roman emperor Constantine's autocratic regime to that of the Chinese and Saudi Arabian "principalities" in temporal-spatial circumstances or environments that spawned the severe acute respiratory syndrome coronavirus (SARS-CoV) in China in 2002-2003, and the Middle East respiratory syndrome coronavirus (MERS-CoV) that was first identified in Saudi Arabia in 2012.

And might the spawning of the H1N1 influenza in Mexico in 2009 point to a preference of these "crown" (corona) viral biological phenomena for psycho-social climates or conditions that result from the embedding or entrenchement of moral corruption and crime in official state organs?

Note that to the extent that the influenza-influencer interactive model of disease phenomenon that I am 
proposing here is a valid explanation of the H1N1's appearance in Roman Catholicism saturated Mexico, the confusion of the unwritten New Covenant with the written New Testament in the first and second century $\mathrm{AD}$ and its nationalist-imperial consolidation under Constantine can also be construed as an epoch jumping and/or intergenerational ethical disease.

And I note that Jeremiah's anouncement of the NC phenomenon is immediately preceded by a reference to what appears to have been a well known ethical maxim that explained illness or other ill-fortune as a consequence of heredity:

"In those days, it will no longer be said: 'The fathers have eaten sour grapes, and this has set the children's teeth on edge. Instead, each will die for his own iniquity. If anyone eats the sour grapes, his own teeth will be set on edge."

The spiritual NC phenomenon, which transcends written material and related legalism, is therefore introduced as a kind of hereditary "circuit breaker", stemming the spread of all destructive human contagion - at least from 
the time of Jeremiah, through to the emrgence of COVID19.

Equating the NC with conscience, as I do most explicitly in The Bible: Beauty and Terror Reconciled (2010), I have traced its existence, in one form, ideation/incarnation or iteration or another, to humanity's emergence on the African continent.

And I underscore this point as much out of a duty of care for myself, a melanin rich, phenotypically Black Barbadian, as out of my care for other Barbadians, like historian Trevor Marshall, who apparently struggle to appreciate the intricacies of my Pan Humanist brand of Pan Africanism.

Seasoned in Barbados' 98\% literacy aided and abetted gender, racial and religious politics of information inflammation, I empathise with Marshall's and others' capacity for Black Nazi, Feminazi and similar grand designs and delusions.

I consider myself a fellow traveller and struggler with the late Nation newspaper publisher emritus Harold Hoyte, journalists Al Gilkes, Anthony Blackman, Kaymar Jordan, 
Carol Martindale, Roxanne Gibbs and other scribes who have survived Hoyte.

I too struggle to manage my cognitive cholesterol: I struggle with literacy aided and abetted information addiction, related memory afflictions and ungrounded ambition induced strangleholds.

Certainly, having been an evangelical fundamentalist Pentecostal Christian, I have deep personal knowledge of the historical hallucination inducing capacity of the written NT.

And I have spent much of the last ten years, at least, trying to explain to colleagues and comrades in Britain's National Union of Journalists (NUJ) and similar atheistic or secular writer enclaves, how literacy can lead to information inflammation irrespective of its ideological canon or carcass.

By my analysis, the historical hallucination inducing capacity of the written NT canon (the last 27 books of the Bible, from Matthew to Revelation) is comparable with the "penetrative, or binding power" of the COVID-19 protein spikes mentioned above. 


\section{"The fundamental things apply, as time goes by"}

So actually, I am not proposing a COVID-19

causation narrative that differs fundamentally from that embraced by the global scientific community.

Rather, I am urging consideration of the possibility that incidence of the disease be viewed as a kind of bookbound-and-binding act of believing in which the genetic or hereditary DNA material of one's sense of identity and world view, the foundational function of conscience, feature's prominently.

My proposition presupposes an isomer approximating or isometric relationship between breathing and believing.

And, of course, one's sexuality and procreative origin and potential - one's gender identity, roughly - features prominently in one's sense of identity.

The bio-psychological scripting or sense of who one is and what one is scripted or bound to be and do constitutes a sort of categorical imperative (Kant), arguably. 
It binds or locates one's temporal-spatial ground of being (Tillich) in the cosmological battle of the sexes.

Accordingly, the apostle Paul, the Church Father Tertullian and other early Christian writers of note might be construed as superspreaders, who consciously or unconsciously inscribed their ancestral addresses (genetic markers or spiritual signatures) "on the envelope" which surrounds SARS-CoV-2's ancient, core graphic-genetic material.

President Trump, who I have previously likened to the beast of Revelation, his presidential rival Joe Biden, Pope Francis, the Queen of England, Barbados prime minister Mia Mottley, New Zealand's Jacinda Adern and all other world leaders and influencers, of ancient pedigree or novel "publication" (or publicanism?), could therefore also be assessed in terms of how they deliver the "letter" that kills (2 Corinthians 3:6) - or in line with the procreative binding or undermining "battle of the sexes" framework, how they deliver the scriptural kisss of death.

And I am more indebted to the little known American song writer Herman Hepfeld than I am to the biblical traitor Judas for the "kiss" metaphor that I am using to 
explain this marital-procreative epidemiological construct.

On November 3, 2020, as I was preparing this article, I heard the words "The fundamental things apply" from Hepfeld's classic song "As time goes by", immortalized in the film Casablanca.

An excerpt of the song that contains those words is featured in the second episode of The Sanest Guy in the Room, the award winning lyricist Don Black's "warm and wonderfully moving memoir", read by Black on BBC Radio Four's Book of the Week.

I immediately made the link between those words and the perennial, beauty and terror of the battle of the sexes, and of humanity with COVID-19 that I am treating here.

And thus induced to listen to other episodes of the "causation narrative" that the legendary songwriter and creative force Black shares about his own and his late wife Shirley's (indirect) contribution to some of the twentieth century's biggest hits, I was reacquainted with his classic Born Free, a personal favourite. 
And then I was almost immediately struck by the potentially truth twisting, "terror" of that songs lyrics: a tribute to freedom that takes the mind captive, potentially.

It occurred to me that Born Free can be as much a war song, as a song of peace.

It occurred to me that this 1966 Black classic can as surely be a "battle cry" as the would be peace-maker Bob Marley's song "War" can.

And it is arguably as simplistic as the Jamaican Reggae music icon Marley's rape-like reduction of the Ethiopian emperor Haile Selassie's speech: a kind of piracy or plagiarism.

I discuss Marley's conscious or unconscious mangling or mauling of the essential peace-making message that distinguished Selassie's 1963 address to the United Nations elsewhere.

He and other charismatic songwriters, who straddle the realm of letter and spirit, as Black suggests, bear a peculiar social responsibility. 
I note that Barbadian "Queen of Soca", Allison Hinds' assertion that she is not a role model was made many years ago - and, significantly, before she became a mother.

I also recall a comment by former National Cultural Foundation (NCF) literary arts officer Katie Gash, who empathised with fellow female writer Nailah Imojah's (formerly Charmaine Gill) delusional claim to foundational work I had done among Barbados' literary community in the 1980s and 1990s.

Gash suggested that Imojah had acted unethically, overstating her contribution to Barbados|contemporary cultural renaissance and negating my contribution, effectively, because she was not a mother.

At the time Imojah was a teacher but she had no children of her own.

The implication was that Imojah, whose delusional, consciously or unconsciously deceitful, glory grabbing behavior led to her employment as Literary Officer by Barbados' National Cultural Foundation (NCF), somehow 
confused literary creativity with procreation: a case of NC-NT confusion by the NCF, essentially.

I am proposing that Nailah's influence and that of other illusion or influenza superspreader proximating influencers could be assessed in terms of how much they consciously or unconsciously encourage the people they inspire, mentally "massage", musically "message" (McLuhan) or otherwise infect, to develop that "catastrophic, or at least perilous bio-psychological permeability" that I am proposing is the bride (or bribe?) of COVID-19.

Note that it is Nailah who I call Lie-e-lah in my landmark 2005 article Fundamentalist Feminism.

Readers should also note that Barbados' current PM Mottley was responsible for the NCF at the time that it adopted the maladpted, others'-credit-claiming, fruit-ofothers'-wit-womb-labor misappropriating Imojah.

I am proposing that just as we are all succeptable, to varying degrees, to skin cancers and other disease insults that accompany increased entry of solar ultra violet rays into human's habitable atmosphere, with the annual 
depletion of earth's ozone envelope, we are clearly all also succeptable at an intergenerational or perenial level to what I have called "the cerebral fossilization or 'brain death'" that has ensued from the Church Fathers' confusion of the unwritten NC with the written NT, and similar malformations of conscience and intelligence (nous, gnosis) that predate that Judeo-Christian instance or iteration of bio-psychic carcinogenesis.

And the African Ubuntu concept, especially as articulated by Zimbabwean nationalist Stanlake Samkagne is a wellknown indigenous construct of interdependent reality or relationship that predates Christianinty, Marxism and other ideologies.

And noting the disproportionate COVID-19 death rate among Black and Minority Ethnic (BAME) communities in the UK and elsewhere, I am particularly concerned about instances of such carcinogenic confusion of biology and biography that can be traced to Africa, the perennial cradle and grave of civilization. 
Might the kind of patriarchal misstep or grave mistake that Samkange suggests the Zulu king Lobengula made in his dealings with the British imperialist Cecil Rhodes be explained in terms of bio-psychological permeability?

I feel certain of this.

I also believe that the "unconventional" African animism derived cosmology that Cameroonian-American physician and pastor Dr Stella Immanuel has been superspreading is not entirely without medicinal merit as COVID-19 battling strategy.

Sadly, a NC-NT mimicking marital mirage of the evangelical Christian Immanuel's NT based literalism and the book bound bigotry of "scientific" secularism may be presenting her and persons critical of her, like CNN journalist Anderson Cooper, from appreciating the extent to which their self-understandings and world views are interdependent with the temporal-spatial environments that surround or encompass them - like the Elsa-esque lioness in Jeremiah's NC causation, conscience formation narrative surrounds its quarry. 
The one-hole warri (Oware) of the Caribbean, the two wickets of cricket and its trinitarian stumps all attest, as does glossolalia, also known as "speaking in tongues" to a simultaneously carnal and transcendental way of knowing (gnosis): a coronal carnal knowledge norm at the heart of human existence.

The recommendation of Tai Chi Chuan therapy by the British National Health Service (NHS) suggests an openness to alternative understandings of science that could mean the difference between life and death for some people in their COVID-19 battle.

Perhaps some research by British and American secular scientists into the clearly more privileged and respected Chinese art of Tai Chi Chuan - privileged and respected relative to the low regard, modeled by Cooper, that many British and American scientists have for African knowledge systems - might produce a useful evidentiary bridge from Immanuel's "spirit spouse" diagnostic cosmology to the NC heiros gamos that Jeremiah predicted some time between 626 and 587 BC, approximately. 


\section{Background - gender discourse diglossia}

In a petition to Pope Francis that I initiated in September 2019, I write:

There is compelling evidence that during the second century AD, Marcion, Origen, Tertullian and other "Church Fathers" confused the UNWRITTEN, spiritual principle called the New Covenant by the prophet Jeremiah in the Bible (Jeremiah 31:31-34) with the New Testament, a collection or "canon" of WRITTEN materials.

These Christians, their Jewish ancestors, Islamic successors and other bookish believers therefore bear significant, catalytic historical responsibility for the cerebral fossilization or "brain death" that has ensued from that Church Fathers' error, whether committed consciously or unconsciously.

In that petition I also mention "the Yin that can compliment or contaminate the Yang of literacy." 
(Might this be usefully construed as an isometric trait of literacy?)

And refuting the suggestions of News International's Rupert Murdoch, the BBC's Stuart Hall and other prominent traditional media representatives that Facebook, Twitter, Google and other internet based "social media" monopolies are to blame for the proliferation of "fake news" and all the other evils afflicting contemporary communication, I argue that these "new (generation) media" have only compounded underlying challenges.

"They have not created those challenges," I insist.

I argue "Literacy itself is implicated in the academic anxiety, legalism, literalism and related psychosocial tensions and mental health crises in Barbados, Jamaica, India, Nigeria, the United Kingdom, the United States, France, Germany, Italy and other places."

And this opinion of literacy has been informed by the understanding of the interplay or complementarity of beauty and terror that I set out in my book The Bible: Beauty And Terror Reconciled (TBBTR). 
And a similar rational, arguably Kantian, measurement or reconciliation of beauty and terror, faith and fear is at the heart of my booklet Woman-I-Zen, a "study of the feminine principle - or, of soft power" (Campbell, 2013).

But I have been keenly exploring the psychosocial impact or imprint of the batty "battle of the sexes" and related gender dynamics associated with the distribution of power on unwritten NC tensions or dis-ease of conscience for many years, as I recently indicated to the self-taught American academic Charles E Peck Jr.

That exploration, reflected in research I did for UNIFEM (UN Women's predecessor) in the 1990s, was already considerably advanced and yeilding evidence of what might best be described as gender racketeering induced diglossic fossilizations when I discovered the research done by Dr Lisa Littman into what she calls "a rapid onset of gender dysphoria".

Littman's study furnishes evidence of a "social contagion" that can be traced to the batty, bi-polar broadcasted thinking of contemporary mainstream and social media influencers like the transwoman Caitlyn Jenner, gay parenting pop music crusaders Sir Elton John and 
Madonna, the current Barbados Prime Minister Mottley and other champions of legalistic, written New Testament proximating "political homosexuality" around the world.

And I am careful to distiguish here between individual cases of homosexual ideation and its mass media propagated political variants.

I published my concerns about this advertizing industry "aided and abetted", celebrity super spreader sprayed pandemic-of-NC-NT-confusion-mirroring gender confused and clustering strain of homosexuality on September 22, 2020, in a statement responding to prime minister Mottley's announcement of her plans to legalize same sex unions in our island home.

That statement asserts both my decades long support for the human rights of gay people and "my concern about the dangerous, intrusive 'liberties' being taken by some celebrity and other excessively influential homosexuals...".

I wrote "Since 2012, at least, I have been publishing my concerns about the socioeconomic and sociopolitical 
'overbite' or 'overreach' of these 'gay gospel' apostles and their heterosexual allies (people like David Cameron, Barack Obama and Madonna) who politically and commercially 'commodify' human sexuality and other core, critical features of human identity, consciously or unconsciously."

Note the similarity between the effect of "classical conditioning" that I address in that statement and the influence of peer or social contagion and the influence of medical professionals and the media that Littman's research documents and explores.

Under the heading "Covert classical conditioning by gay media interests", I wrote:

Is there a substantial difference between the written New Testament aided and abetted Christian "gay conversion therapy" practices that many gay rights advocates denounce, and the simplistic legalistic, New Testament proximating "canonical" promotion of a homosexual orthodoxy from primary, through tertiary and other formal and informal educational 
settings (especially via the print and electronic media) and in other public fora that those same advocates applaud?

From my perspective, they seem to be of the same controversial, potentially abusive, secretive social conditioning intent as the "Little Albert" experiment featured in the film above.

The film referred to there is about behaviorist John B Watson's controversial research that saw him subject an eleven month old infant named Albert to traumatic experiences in a replication of Ivan Pavlov's work with dogs.

Painful to watch, some extracts of Watson's fear conditioning experiment featured in the film are comparable, at an indirect or micro aggressive level, to the images of beheadings and other acts of brutality and inhumanity that Muslim extremists use in their psychological warfare advertizing campaigns.

And the photo of a stream of immigrants supposedly threatening to overrun the UK that was deployed by the 
then Nigel Farage led UKIP in Britain's 2016 referendum on EU membership also comes to mind here.

As does Sir Elton's social media and mainstream media "aided and abbetted" conspiratorial campaign against the designers Dolce and Gabana.

John, who shares two sons with his husband David Furnish, launched a "boycott Dolce and Gabana" campaign because those two gay men had the audacity to express a view that dissents from the narrative of gay parenting that he, Sandi Toxfig and others dominating homosexual rights advocacy are propagating and comfortable with.

When I mentioned "a subtle Jihadi mirroring, fascist 'gay gospel' militancy" in a preceding paragraph here, I had John's and others' freedom of speech and related human rights trampling behavior in mind.

Notably, Littman documents similar evidence of fascistic prejudice by members of transgender youth clusters (friendships, Facebook and other online groups, for example) against heterosexual people, who gay fascists 
label "cis privileged" and similar labels denoting evil intent or culpable ignorance.

And Littman clearly had hijackings of homosexuality and gender transitioning narratives by such influential clusters in mind when she wrote about "social contagion".

And note how her account of the "scripted" or parroting behavior of the adolescent and young adults that she studied aligns with my likening of the binding power of the SARs-CoV-2 spikes to the bookish binding potency of the written New Testament.

My recent outreach to French president Emmanuel Macron, drawing his attention to the role of the written NT in facilitating Christendom's shameful, tragic legacy of intolerance and violence attests not just to the relevance but the urgency of the difference between the unwritten NC being taken to heart.

On October 26 I delivered that "open letter", which essentially compares the mind binding or bending power of the written NT and the Koran, to president Macron in an 8-tweet Twitter thread. 
In tweet number three of that thread I ask: "Is Islam more in crisis than its "bookish theoric" (Shakespeare) siblings Christianity \& Judaism? Indeed, the youngest of the three, Islam's propensity for adolescent brashness and brutality can at least be understood. While sternly denounced, it can possibly be forgiven."

\section{Conclusion}

"Since the emergence of SARS-CoV-2 in December 2019, there has been an unparalleled global effort to characterise the virus and the clinical course of disease," writes Muge Celik et al in a recent edition of the BMJ (BMJ 2020;371:m3862).

And they continue "Coronavirus disease 2019 (covid-19), caused by SARS-CoV-2, follows a biphasic pattern of illness that likely results from the combination of an early viral response phase and an inflammatory second phase."

Might there be some psychosomatic correspondence, if not a parallel, between that biphasic pattern of illness 
and the bipolar, gender, race and religious racketeering thinking and behavior that I exlore in a September 2017 article titled Trump's bipolar Bajan 'head teachers' (Heady black and white nationalist alliances - part 1)?

Celik and his co-authors note that most clinical presentations are mild, and that the typical pattern of covid-19 "more resembles an influenza-like illnesswhich includes fever, cough, malaise, myalgia, headache, and taste and smell disturbance-rather than severe pneumonia (although emerging evidence about long term consequences is yet to be understood in detail)."

Their review provides "a broad update on the emerging understanding of SARS-CoV-2 pathophysiology, including virology, transmission dynamics, and the immune response to the virus."

Mindful of the evolving nature of the virus they concede that any of the mechanisms and assumptions discussed in the article and in their understanding of covid-19 may be revised as further evidence emerges. 
I am hoping that the "metaphysical" medical perspective I am offering here will be received in that spirit of openness to evolving, empirical evidence.

I am hoping that this arguably "spikey" article will be receved by the "ACE2 receptors" of the medical and wider scientific comunity in the spirit in which I wrote it: that is to say, I hope that they will align their critical thinking faculties with the good intentions - or as Christian apologist CS Lewis might say, the "good infection" - of my hypothesis.

Among other things, this should lead to an exploration of issues that epidemiologists studying SARS-CoV-2 and COVID-19 may not have considered relevant previously.

Issues to do with reading patterns and other literacy related information consumption by persons contracting or "covenanting" with COVID-19 is the most obvious of these issues.

The open ideological and interdisciplinary scope of my alternative COVID-19 causation narrative also invest in and invite inquiry from an array of disciplines, including 
history, geography, biology, physics, linguistics, neuroscience, psychology and theology.

\section{References}

https://youtu.be/moV1aBVYKGA

https://www.bmj.com/content/371/bmj.m3862

https://youtu.be/N8-Vli7tb44

https://www.ncbi.nlm.nih.gov/books/NBK554776/ (atypical [psychological] symptoms)

https://www.businessinsider.com/rare-uncommonsymptoms-of-covid-19-coronavirus-2020-3? $r=U S \& I R=T$

https://www.forbes.com/sites/johnhall/2018/10/10/3ways-this-startup-aims-to-democratize-bookpublishing/?fbclid=IwAR3tTm-Slv7Bd2jhrVhVjMitsie1vrDjxRjh vXl8lyp\&sh=7d37ac1421c2\#77b065032 $\underline{1 c 2}$

https://www.nhs.uk/conditions/swine-flu/ 
https://www.ncbi.nlm.nih.gov/pmc/articles/PMC609557 8/

https://en.wikipedia.org/wiki/Categorical imperative https://en.wikipedia.org/wiki/Immanuel Kant http://www.bbc.co.uk/caribbean/news/story/2004/12/p rintable/041213 alisonhinds-departure.shtml https://www.nytimes.com/1988/03/09/obituaries/stanla ke-samkange-zimbabwe-politician-65.html https://en.wikipedia.org/wiki/Stella Immanuel https://en.wikipedia.org/wiki/Spirit spouse https://korebelief.com/mouth-of-the-beast/intelekinternational-statement-on-barbados-pm-plans-tolegalize-gay-unions/

https://www.change.org/p/pope-francis-i-please-helpprevent-bible-based-brain-death-pope-francis https://en.wikipedia.org/wiki/Observations on the Feel ing of the Beautiful and Sublime 
https://www.academia.edu/42899287/Deconstructing d ickhead a cocksure COVID 19 cure for men Part On $\underline{\mathrm{e}}$

https://en.wikipedia.org/wiki/Don Black (white suprem acist)

https://en.wikipedia.org/wiki/Don Black \%28lyricist\%29 https://biblehub.com/psb/ieremiah/31.htm https://www.bbc.co.uk/sounds/play/m000p0zl https://youtu.be/AxuwazaXOMg https://www.youtube.com/watch?v=FdAh2HJ98WE https://www.msn.com/en-us/news/us/racial-violenceand-a-pandemic-how-the-red-summer-of-1919-relatesto-2020/ar-BB15MxcN?ocid=sf

https://www.psychologytoday.com/us/blog/youremotional-meter/202003/anxiety-vs-coronavirus-howtell-the-difference

https://www.businessinsider.com/half-of-residents-carehome-infected-coronavirus-covid19-no-symptoms-2020$\underline{3 ? r=U S \& I R=T}$ 
https://www.britannica.com/topic/diglossia

https://youtu.be/9hBfnXACsOI

https://www.britannica.com/biography/John-B-Watson

https://korebelief.com/mouth-of-the-beast/trumpsbipolar-bajan-head-teachers-heady-black-and-white-

nationalist-alliances-part-1/ 